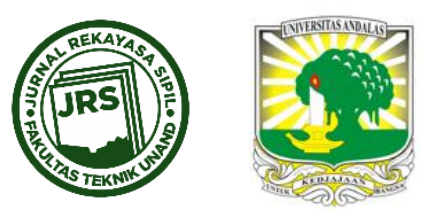

\title{
PERSEPSI OWNER TERHADAP KOMPETENSI MANAJEMEN KONTRAKTOR JALAN DI SUMATERA BARAT
}

\author{
EVITA KARTIKARATU REPADI ${ }^{1}$, YOSRITZAL $^{2}$, PURNAWAN $^{3}$ \\ ${ }^{1}$ Prodi Magister Teknik Sipil, Fakultas Teknik, Universitas Andalas (evitaratu88@yahoo.com) \\ 2Jurusan Teknik Sipil, Fakultas Teknik, Universitas Andalas (هyosritzal@ft.unand.ac.id) \\ ${ }^{3}$ Jurusan Teknik Sipil, Fakultas Teknik, Universitas Andalas (purnawan@ft.unand.ac.id)
}

Naskah diterima : 4 September 2017. Disetujui: 25 September 2017. Diterbitkan : 22 Oktober 2017

\begin{abstract}
ABSTRAK
Dalam menunjang keberhasilan pembangunan infrastruktur, maka diperlukan kerja sama yang baik antara owner, kontraktor dan konsultan yang harus didukung dengan penerapan sistem manajemen proyek. Beberapa penyebab keterlambatan penyelesaian proyek pada Dinas Prasarana Jalan, Tataruang dan Permukiman Prov. Sumbar berhubungan dengan penerapan sistem manajemen proyek yang masih rendah, Penelitian ini bertujuan untuk mengidentifikasi faktor-faktor yang berpengaruh terhadap kinerja manajemen proyek kontraktor jalan untuk paket non kecil di Prov. Sumatera Barat, mengetahui persepsi owner terhadap penyedia jasa konstruksi dan memberikan gambaran mengenai kinerja manajemen proyek yang perlu ditingkatkan kinerjanya oleh kontraktor nonkecil jalan di Prov. Sumatera Barat. Dari penelitian ini teridentifikasi terdapat 9 faktor yang mempengaruhi kompetensi manajemen kontraktor jalan, Melalui metode CSI diketahui nilai Customer Satisfaction Index (CSI) sebesar 69\% yang terletak pada rentang nilai antara $65 \%<$ CSI $\leq$ $80 \%$ ) yaitu level ke IV (Puas) sehingga Owner merasa puas terhadap kompetensi manajemen kontraktor paket nonkecil yang bekerjasama dengan Dinas Prasarana Jalan, Tataruang dan Permukiman Provinsi Sumatera Barat, Dengan Metode Requirement Satisfacton Analysis yaitu metode kuadran dan gap analysis diketahui terdapat 3 faktor yang menjadi fokus dalam perbaikan yaitu faktor sistem manajemen pelaksanaan jalan, faktor administrasi dan dokumentasi dan faktor sumber daya. Faktor administrasi dan dokumentasi adalah faktor yang memiliki Gap (selisih nilai) kebutuhan dan kepuasan yang paling besar sehingga menjadi faktor yang paling prioritas untuk ditingkatkan kinerjanya karena sangat berpengaruh terhadap kinerja kompetensi manajemen kontraktor jalan untuk paket nonkecil di Provinsi Sumatera Barat.
\end{abstract}

Kata kunci : Manajemen Kontraktor, Customer Satisfaction Index, Requirement Satisfaction Analysis

\section{PENDAhULUAN}

Pembangunan jalan di Sumatera Barat sedang gencar-gencarnya dilaksanakan, Guna keberhasilan pembangunan infrastruktur ini, maka diperlukan kerja sama yang baik antara owner, kontraktor dan konsultan yang harus didukung dengan penerapan sistem manajemen proyek. Beberapa hal penyebab keterlambatan penyelesaian proyek pada Dinas 
Prasarana Jalan, Tataruang dan Permukiman ( Dinas Prasjal Tarkim) Provinsi Sumatera Barat adalah sebagai berikut :
a. Keterlambatan terkait material.
b. Keterlambatan terkait tenaga kerja.
c. Keterlambatan terkait peralatan.
d. Perencanaan yang tidak sesuai.
e. Lemahnya kontrol waktu proyek.
f. Keterlambatan Subkontraktor.
g. Koordinasi yang lemah.
h. Pengawasan yang tidak memadai.
i. Metode pelaksanaan yang tidak sesuai.
j. Kurangnya personil secara teknikal

Dari uraian tersebut, maka dapat dilihat penyebab keterlambatan penyelesaian proyek pada Dinas Prasarana Jalan, Tataruang dan Permukiman (Dinas Prasjal Tarkim) Provinsi Sumatera Barat berhubungan dengan penerapan sistem manajemen proyek yang masih rendah, Oleh karena itu dilakukan penelitian ini dapat memberikan gambaran mengenai kinerja manajemen proyek serta mengetahui faktor yang perlu ditingkatkan kinerjanya oleh kontraktor nonkecil jalan di Provinsi Sumatera Barat.

\section{STUDI PUSTAKA}

\subsection{Definisi Manajemen Proyek}

Manajemen proyek menurut Project Management Body of Knowledges yang dikutip oleh Khasani (2013) adalah aplikasi atau implementasi dari pengetahuan, keterampilan, perangkat dan teknik pada suatu aktivitas proyek untuk memenuhi kebutuhan dan tujuan suatu proyek, Hubungan pihak-pihak yang terlibat langsung dalam manajemen proyek dinyatakan dengan diagram pada Gambar 1 sebagai berikut :

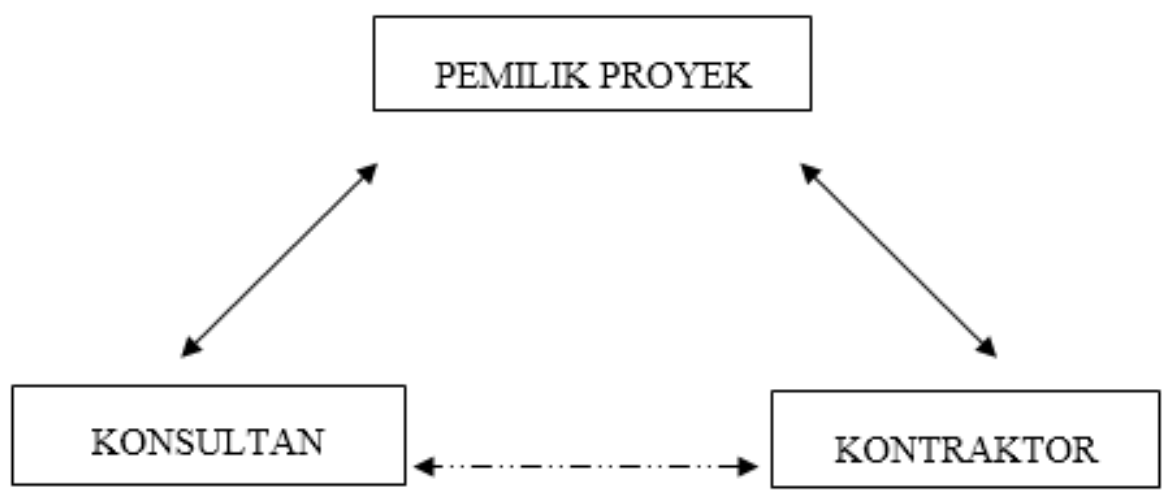

Gambar 1. Hubungan Pihak-pihak Yang Terkait Manajemen Proyek

\subsection{SKKNI Manajer Lapangan Pekerjaan Jalan}

Berdasarkan Standar Kompetensi Kerja Nasional Indonesia jabatan Manajer Lapangan Pekerjaan Jalan yang ditetapkan oleh Kementerian Pekerjaan Umum, beserta Lembaga Pengembangan Jasa Konstruksi Nasional (LPJKN) mengenai Pengetahuan dan Keterampilan yang dipersyaratkan untuk seorang manajer lapangan. 


\subsection{Penelitian di Indonesia yang menjadi bahan referensi}

Tabel 1. Penelitian terdahulu terkait kompetensimenyajikan rangkuman penelitian yang pernah dilakukan:

Tabel 1. Penelitian terdahulu terkait kompetensi

\begin{tabular}{|c|c|c|c|}
\hline $\mathrm{NO}$ & PUBLIKASI & JUDUL PENELITIAN & HASIL PENELITIAN \\
\hline 1 & $\begin{array}{l}\text { Melriansyah } \\
(2011)\end{array}$ & $\begin{array}{l}\text { Permodelan kompetensi } \\
\text { knowledge, Behavioral dan } \\
\text { contextual manajer proyek } \\
\text { Sebagai faktor kesuksesan } \\
\text { manajer proyek terhadap } \\
\text { kinerja biaya proyek. }\end{array}$ & $\begin{array}{l}\text { Di ketahui manajer proyek merupakan } \\
\text { suatu faktor penting yang dibutuhkan } \\
\text { proyek untuk dapat menjadikan proyek } \\
\text { yang sukses yang harus menguasai } 4 \\
\text { kelompok faktor yaitu faktor } \\
\text { Organizational Context, faktor Team } \\
\text { Builder, faktor Communication, faktor } \\
\text { Personal Self Behaviour. }\end{array}$ \\
\hline 2 & $\begin{array}{l}\text { Budhi Susilo } \\
(2000)\end{array}$ & $\begin{array}{l}\text { Analisis pengaruh faktor } \\
\text { sikap, keahlian dan } \\
\text { pengetahuan terhadap } \\
\text { kompetensi manajemen } \\
\text { perusahaan konstruksi dari } \\
\text { sudut pandang owner, } \\
\text { konsultan dan sub } \\
\text { kontraktor (studi kasus } 4 \\
\text { perusahaan konstruksi } \\
\text { golongan A di Surabaya). }\end{array}$ & $\begin{array}{l}\text { Di ketahui Hasil anova } 1 \text { jalur yang } \\
\text { menunjukkan adanya kesamaan } \\
\text { pandangan diantara responden dan } \\
\text { pemilik proyek dan Hasil anova } 2 \text { jalur } \\
\text { pada rerata menurjukkan bahwa nilai } \\
\text { faktor kompetensi, sikap, keahlian dan } \\
\text { pengetahuan yang paling baik pada satu } \\
\text { perusahaan X. }\end{array}$ \\
\hline 3 & $\begin{array}{l}\text { Andy Wahyu } \\
\text { Hermanto } \\
(2008)\end{array}$ & $\begin{array}{l}\text { Analisa tingkat kepuasan } \\
\text { konsumen terhadap } \\
\text { pelayanan } \\
\text { terminal peti kemas } \\
\text { semarang. }\end{array}$ & $\begin{array}{l}\text { Disimpulkan pengguna jasa Terminal } \\
\text { Peti Kemas Semarang untuk kegiatan } \\
\text { ekspor barang sudah cukup puas dengan } \\
\text { kondisi dan kualitas pelayanan saat ini } \\
\text { dan untuk meningkatkan daya tarik } \\
\text { perlu ditingkatkan beberapa faktor. }\end{array}$ \\
\hline 4 & $\begin{array}{l}\text { Riqi Radian } \\
\text { Khasani } \\
(2013)\end{array}$ & $\begin{array}{l}\text { Evaluasi kepuasan } \\
\text { pelanggan terhadap kinerja } \\
\text { manajemen } \\
\text { proyek kontraktor besar } \\
\text { Bangunan gedung. }\end{array}$ & $\begin{array}{l}\text { Dari hasil analisis didapatkan beberapa } \\
\text { faktor-faktor kinerja manajemen proyek } \\
\text { kontraktor besar yang telah } \\
\text { memuaskan, perlu mendapat prioritas } \\
\text { perbaikan, berprioritas rendah, dan } \\
\text { dianggap berlebiha guna meningkatkan } \\
\text { performa kinerjanya. }\end{array}$ \\
\hline 5 & $\begin{array}{l}\text { Yosritzal } \\
\text { dkk } \\
(2015)\end{array}$ & $\begin{array}{l}\text { Studi Implementasi } \\
\text { Metoda Importance- } \\
\text { Satisfaction Analysis (ISA) } \\
\text { pada Penentuan Prioritas } \\
\text { Penanganan } \\
\text { Pelayanan Kereta Api } \\
\text { Padang-Pariaman. }\end{array}$ & $\begin{array}{l}\text { penggunaan salah satu metoda } \\
\text { penelitian dapat mengakibatkan tidak } \\
\text { optimalnya penanganan yang dilakukan } \\
\text { sehingga sebaiknya kedua metoda } \\
\text { dilakukan dan item dengan prioritas } \\
\text { utama menurut } \\
\text { kedua metoda ini yang dijadikan } \\
\text { prioritas utama penanganan. }\end{array}$ \\
\hline 6 & $\begin{array}{l}\text { Rudy } \\
\text { Setiawan } \\
(2005)\end{array}$ & $\begin{array}{l}\text { Analisa Tingkat Kepuasan } \\
\text { Pengguna Kereta Api } \\
\text { Komuter Surabaya- } \\
\text { Sidoarjo. }\end{array}$ & $\begin{array}{l}\text { Dari penelitian ini disimpulkan bahwa } \\
\text { pengguna KA komuter cukup puas } \\
\text { dengann pelayanan saat ini dan } \\
\text { didapatkan beberapa faktor untuk } \\
\text { meningkatkan daya tarik pengguna. }\end{array}$ \\
\hline
\end{tabular}




\section{HASIL, ANALISA DATA DAN PEMBAHASAN}

\subsection{Identifikasi Faktor-faktor Kompetensi Manajemen Kontraktor}

Faktor-faktor yang berpengaruh terhadap kinerja manajemen proyek kontraktor didapatkan dari hasil adopsi SSKNI Manajer Lapangan Pekerjaan Jalan 2003 dan merujuk kepada Spesifikasi Teknis 2010 revisi 3 yang disesuaikan dengan kondisi/kebutuhan Dinas Prasrana Jalan, Tataruang dan Permukiman Provinsi Sumatera Barat. seperti yang terlihat pada Tabel 2 .

Tabel 2. Faktor Kompetensi Manajemen Kontraktor Jalan

\begin{tabular}{ll}
\hline Poin & Faktor Kompetensi Manajemen Kontraktor Jalan \\
\hline A & Pengorganisasian sesuai dengan dokumen kontrak dan spesifikasi teknik. \\
\hline B & Rekayasa lapangan. \\
\hline C & Metode pelaksanaan dalam proses konstruksi \\
\hline D & Keahlian dalam melakukan perhitungan biaya konstruksi jalan \\
\hline E & Rencana dan pengendalian mutu, waktu dan biaya \\
\hline F & Sistem manajemen pelaksanaan jalan \\
\hline G & Administrasi dan dokumentasi \\
\hline H & Teknik negosiasi dan hubungan dengan masyarakat \\
\hline I & Sumber daya \\
\hline
\end{tabular}

\subsection{Uji Reliabilitas Data ( Uji Alpha Cronbach)}

Dari hasil uji statistik dengan menggunakan SPSS versi 20 didapatkan nilai Alpha Cronbach untuk kepuasan sebesar 0,930 dan alpha cronbach untuk kebutuhan sebesar 0.886, ini berarti nilai Alpha Cronbach berada diatas 0,70 sehingga dapat disimpulkan pengukuran kebutuhan dan kepuasan berada pada reliabilitas yang baik.

\subsection{Uji T Mean Kebutuhan dan Kepuasan}

Nilai uji t yang didapatkan dengan program SPSS versi 20 yaitu $t=8,515$, sedangkan $t$ tabel $=2,120$. Nilai uji $\mathrm{t}$ bernilai positif dan lebih besar dari t tabel sehingga disimpulkan terdapat perbedaan bermakna antara mean kebutuhan dan kepuasan oleh karena itu perlu dianalisis lebih lanjut untuk melihat faktor mana yang nilainya perlu dicermati dan menjadi fokus dalam perbaikan.

\subsection{Hasil Customer Satisfaction Index}

Customer Satisfaction Index (CSI) digunakan untuk menentukan tingkat kepuasan pelanggan secara menyeluruh dengan mempertimbangkan tingkat kepentingan dari faktor kinerja manajemen proyek yang diukur (Khasani,2013). Pada penelitian ini metode CSI digunakan untuk melihat kepuasan owner terhadap kompetensi manajemen kontraktor jalan nonkecil secara menyeluruh.

Hasil CSI untuk faktor kinerja manajemen proyek kontraktor nonkecil jalan dapat dilihat pada Tabel 3. 
Tabel 3. Nilai CSI untuk faktor manajemen proyek kontraktor nonkecil jalan

\begin{tabular}{|c|c|c|c|c|c|}
\hline Poin & Uraian & $\begin{array}{l}\text { Mean Skor } \\
\text { (Requireme } \\
\text { nt) }\end{array}$ & $\begin{array}{l}\text { Weighting } \\
\text { Factor }\end{array}$ & $\begin{array}{l}\text { Mean Skor } \\
\text { (Satisfactio } \\
\text { n) }\end{array}$ & $\begin{array}{l}\text { Weighti } \\
\text { ng Score }\end{array}$ \\
\hline $\mathrm{a}$ & $\mathrm{b}$ & th & $\begin{array}{l}\mathrm{d}= \\
(\mathrm{c} / \text { ctotal }) * 100 \%\end{array}$ & th & $f=d^{*} e$ \\
\hline A & $\begin{array}{l}\text { Pengorganisasian } \\
\text { sesuai dengan } \\
\text { dokumen kontrak } \\
\text { dan spesifikasi teknik }\end{array}$ & 3,91 & $10,5 \%$ & 3,38 & 0,353 \\
\hline B & Rekayasa lapangan & 4,01 & $10,7 \%$ & 3,50 & 0,376 \\
\hline $\mathrm{C}$ & $\begin{array}{l}\text { Metode pelaksanaan } \\
\text { dalam proses } \\
\text { konstruksi }\end{array}$ & 4,21 & $11,3 \%$ & 3,48 & 0,392 \\
\hline $\mathrm{D}$ & $\begin{array}{l}\text { Keahlian dalam } \\
\text { melakukan } \\
\text { perhitungan biaya } \\
\text { konstruksi jalan }\end{array}$ & 4,02 & $10,8 \%$ & 3,60 & 0,387 \\
\hline $\mathrm{E}$ & $\begin{array}{l}\text { Rencana dan } \\
\text { Pengendalian mutu, } \\
\text { waktu dan biaya }\end{array}$ & 4,22 & $11,3 \%$ & 3,51 & 0,396 \\
\hline $\mathrm{F}$ & $\begin{array}{l}\text { Sistem manajemen } \\
\text { pelaksanaan jalan }\end{array}$ & 4,25 & $11,4 \%$ & 3,36 & 0,382 \\
\hline G & $\begin{array}{l}\text { Administrasi dan } \\
\text { dokumentasi }\end{array}$ & 4,47 & $12,0 \%$ & 3,31 & 0,396 \\
\hline $\mathrm{H}$ & $\begin{array}{l}\text { Teknik negosiasi dan } \\
\text { hubungan dengan } \\
\text { masyarakat }\end{array}$ & 4,04 & $10,8 \%$ & 3,50 & 0,378 \\
\hline I & Sumber daya & 4,25 & $11,4 \%$ & 3,22 & 0,366 \\
\hline Total & $=$ & 37,38 & $100,0 \%$ & & \\
\hline \multicolumn{5}{|c|}{ Weighted Total $=\{$ Weighting Score $=$} & 3,427 \\
\hline \multicolumn{5}{|c|}{ Satisfaction Index $=(($ Weighted Total $) /$ Scale $(5)) * 100 \%$} & $69 \%$ \\
\hline
\end{tabular}

Berdasarkan Tabel 3 diperoleh nilai CSI $69 \%$ untuk penilaian kepuasan pelanggan sehingga dapat dilihat nilai Customer Satisfaction Index terdapat pada rentang nilai CSI yaitu antara $(65 \%<\mathrm{CSI} \leq 80 \%)$ atau pada level keempat (Puas) sehingga dapat disampaikan secara umum owner merasa puas dengan kompetensi manajemen proyek kontraktor untuk paket nonkecil jalan di Provinsi Sumatera Barat.

\subsection{Hasil Requirement Satisfaction Analysis}

3.5.1. Metode Kuadran dan Gap Analysis dengan Responden PPTK, Kaur TU/teknis dan Pengawas lapangan

Dari hasil penelitian dengan gabungan responden PPTK, Kaur Tu/teknis dan pengawas lapangan didapatkan pemetaan kemampuan dan kebutuhan dengan metode kuadran seperti yang terlihat pada Gambar 2. dan selisih nilai kebutuhan-kepuasan seperti terlihat pada Tabel 4 dan Gambar 3. 


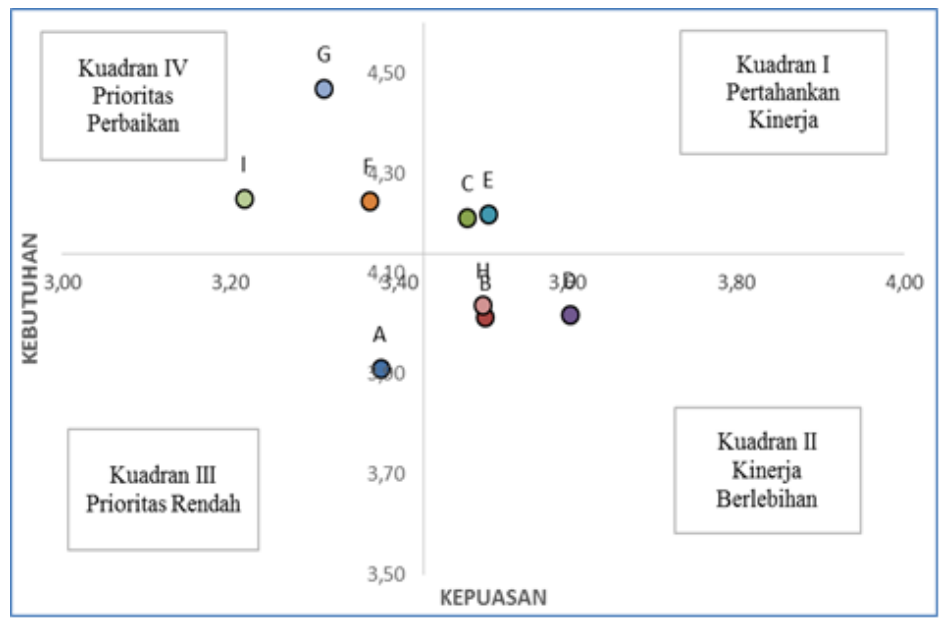

Gambar 2. Diagram kartesius pemetaan kemampuan dan kebutuhan PPTK, Kaur TU/teknis dan Pengawas lapangan.

Tabel 4. Selisih nilai kebutuhan dan kepuasan dengan responden PPTK, Kaur TU/teknis dan Pengawas lapangan.

\begin{tabular}{|c|l|c|c|c|}
\hline Poin & \multicolumn{1}{|c|}{ URAIAN } & $\begin{array}{c}\text { NILAI } \\
\text { KEPUASAN }\end{array}$ & $\begin{array}{c}\text { NILAI } \\
\text { KE BUTUHAN }\end{array}$ & SE LISIH \\
\hline A & $\begin{array}{l}\text { Pengorganisasian sesuai dengan dokumen } \\
\text { kontrak dan spesifikasi teknik }\end{array}$ & 3,38 & 3,91 & 0,53 \\
\hline B & Rekayasa lapangan & 3,50 & 4,01 & 0,51 \\
\hline C & $\begin{array}{l}\text { Metode Pelaksanaan dalam proses } \\
\text { konstruksi }\end{array}$ & 3,48 & 4,21 & 0,73 \\
\hline D & $\begin{array}{l}\text { Keahlian dalam melakukan perhitungan } \\
\text { biaya konstruksi jalan }\end{array}$ & 3,60 & 4,02 & 0,42 \\
\hline E & $\begin{array}{l}\text { Rencana dan pengendalian mutu, waktu } \\
\text { dan biaya }\end{array}$ & 3,51 & 4,22 & 0,71 \\
\hline F & Sistem Manajemen Pelaksanaan Jalan & 3,36 & 4,25 & 0,88 \\
\hline G & Administrasi dan Dokumentasi & 3,31 & 4,47 & 1,16 \\
\hline H & $\begin{array}{l}\text { Tekrik negosiasi dan hubungan dengan } \\
\text { masyarakat }\end{array}$ & 3,50 & 4,04 & 0,54 \\
\hline I & Surrber daya & 3,22 & 4,25 & 1,03 \\
\hline & Rata-rata & 3,43 & 4,15 & 0,72 \\
\hline
\end{tabular}




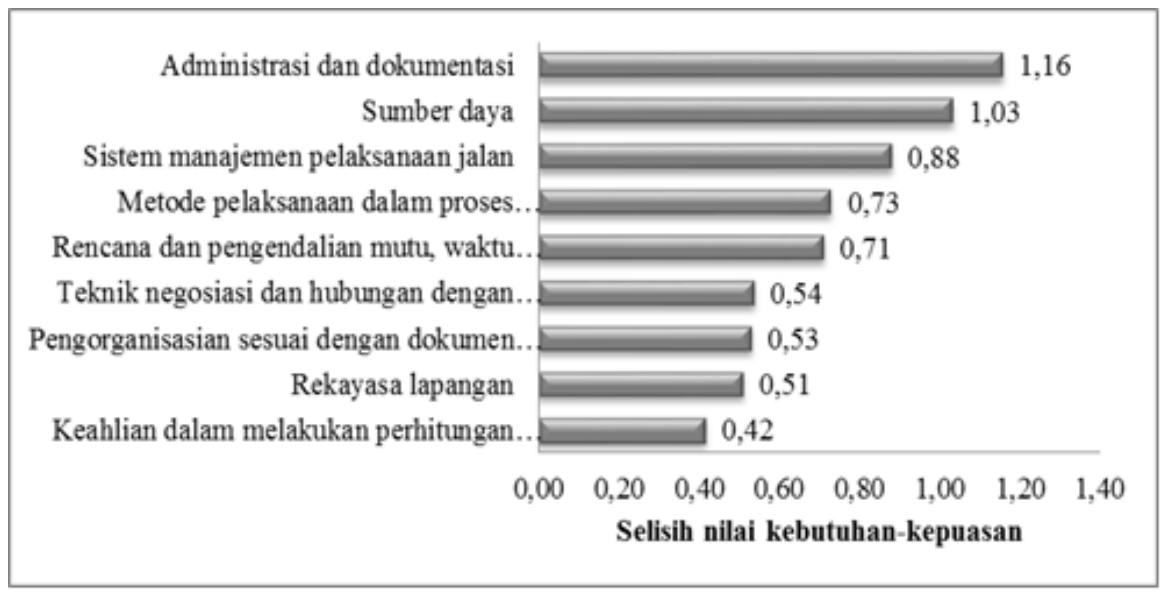

Gambar 3. Bar chart selisih nilai kebutuhan dan kepuasan PPTK, Kaur TU/teknis dan Pengawas lapangan untuk metoda kesenjangan

Sehingga dapat disimpulkan berdasarkan pemetaan kuadran dan gap analysis terdapat 3 faktor yang menjadi fokus dalam perbaikan yaitu faktor sistem manajemen pelaksanaan jalan (poin F), faktor administrasi dan dokumentasi (poin G) dan faktor sumber daya (poin I).

\subsection{Poin Yang Menjadi Fokus Perbaikan (Prioritas)}

Berdasarkan hasil analisa RSA dengan metode Kuadran dan GAP Analysis, poin yang menjadi fokus perbaikan (prioritas) dalam meningkatkan kinerja kontraktor Nonkecil jalan di Sumatera Barat adalah poin F, G, I. Dari masing-masing poin prioritas terdapat beberapa variabel pertanyaan, Selisih nilai kebutuhan dan kepuasan variabel prioritas terlihat pada Tabel 5 dan Gambar 4.

Tabel 5. Selisih nilai kebutuhan dan kepuasan variabel prioritas poin F, G, I.

\begin{tabular}{|c|c|c|c|c|}
\hline Poin & Uraian & $\begin{array}{l}\text { Nilai } \\
\text { Kepuasan }\end{array}$ & $\begin{array}{l}\text { Nilai } \\
\text { Kebutuhan }\end{array}$ & Selisih \\
\hline $\mathrm{F}$ & \multicolumn{4}{|c|}{ SISTEM MANAJEMEN PELAKSANAAN JALAN } \\
\hline 1 & $\begin{array}{l}\text { Kemampuan manajerial dari kepala proyek } \\
\text { baik verbal maupun nonverbal }\end{array}$ & 3,46 & 4,31 & 0,85 \\
\hline 2 & Ketepatan waktu penyelesaian proyek & 3,29 & 4,35 & 1,06 \\
\hline 3 & Penerapan Etika dan Budaya Kerja & 3,38 & 4,08 & 0,70 \\
\hline 4 & $\begin{array}{l}\text { Penyediaan informasi jadwal pelaksanaan } \\
\text { proyek. }\end{array}$ & 3,34 & 4,08 & 0,74 \\
\hline 5 & $\begin{array}{l}\text { Pengambilan keputusan berbasis Data dan } \\
\text { informasi }\end{array}$ & 3,411 & 4,23 & 0,82 \\
\hline 6 & Koordinasi Selama Pelaksanaan proyek & 3,54 & 4,27 & 0,73 \\
\hline 7 & $\begin{array}{l}\text { Keefektifan dalam memilih peralatan yang } \\
\text { dibutuhkan }\end{array}$ & 3,50 & 4,46 & 0,96 \\
\hline 8 & $\begin{array}{l}\text { Pengiriman material ke lapangan penuh } \\
\text { perhitungan }\end{array}$ & 3,37 & 4,35 & 0,98 \\
\hline 9 & $\begin{array}{llll}\begin{array}{l}\text { Penanganan } \\
\text { dilapangan }\end{array} & \text { material yang } & \text { benar } \\
\end{array}$ & 3,43 & 4,15 & 0,73 \\
\hline
\end{tabular}


Persepsi Owner Terhadap Komptenesi Manajemen Kontraktor Jalan di Sumatera Barat

\begin{tabular}{|c|c|c|c|c|}
\hline Poin & Uraian & $\begin{array}{l}\text { Nilai } \\
\text { Kepuasan }\end{array}$ & $\begin{array}{l}\text { Nilai } \\
\text { Kebutuhan }\end{array}$ & Selisih \\
\hline 10 & $\begin{array}{l}\begin{array}{l}\text { Pendistribusian } \\
\text { kebutuhan }\end{array} \\
\text { tenaga }\end{array}$ & 3,28 & 4,19 & 0,92 \\
\hline G & \multicolumn{4}{|l|}{ ADMINISTRASI DAN DOKUMENTASI } \\
\hline 11 & $\begin{array}{l}\text { Kelengkapan Struktur organisasi pengelola } \\
\text { proyek }\end{array}$ & 3,37 & 4,12 & 0,75 \\
\hline 12 & Rutin dan tertib dalam administrasi & 3,22 & 4,65 & 1,44 \\
\hline 13 & $\begin{array}{l}\text { Kesesuaian laporan proyek dengan kondisi } \\
\text { aktual di lapangan }\end{array}$ & 3,51 & 4,65 & 1,14 \\
\hline 14 & Sistem dokumentasi yang terpadu & 3,31 & 4,42 & 1,11 \\
\hline 15 & $\begin{array}{l}\text { Ketersediaan dokumen lengkap proyek } \\
\text { kontraktor }\end{array}$ & 3,32 & 4,50 & 1,18 \\
\hline I & \multicolumn{4}{|l|}{ SUMBER DAYA } \\
\hline 16 & $\begin{array}{l}\text { Personil yang disediakan memenuhi } \\
\text { persyaratan }\end{array}$ & 3,36 & 4,27 & 0,90 \\
\hline 17 & $\begin{array}{l}\text { Peralatan yang disediakan memenuhi } \\
\text { kebutuhan }\end{array}$ & 3,35 & 4,42 & 1,08 \\
\hline 18 & $\begin{array}{l}\text { Bahan tersedia tepat waktu dan berkualitas } \\
\text { baik }\end{array}$ & 3,26 & 4,27 & 1,01 \\
\hline 19 & $\begin{array}{l}\text { Pemilikan Dana Cadangan yang Siap } \\
\text { digunakan }\end{array}$ & 3,06 & 4,04 & 0,98 \\
\hline
\end{tabular}

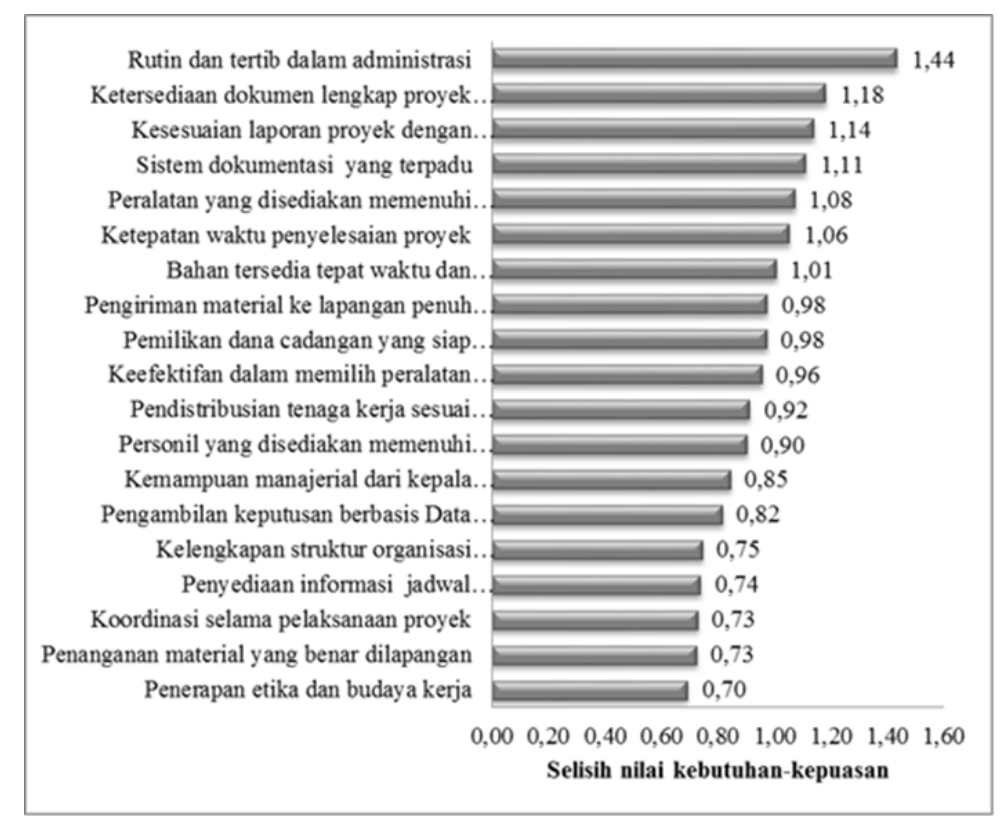

Gambar 4. Bar chart selisih nilai kebutuhan dan kepuasan variabel poin prioritas.

Berdasarkan Tabel 5 dan Gambar 4 terlihat 4 variabel yang terdapat pada poin poin $\mathrm{G}$ (Administrasi dan Dokumentasi ) memiliki selisih nilai kebutuhan dan kepuasan yang paling besar. Keempat variabel dari Poin G tersebut yaitu Rutin dan tertib dalam administrasi, Ketersediaan dokumen lengkap proyek kontraktor, kesesuaian laporan proyek dengan kondisi aktual dilapangan dan Sistem dokumentasi yang terpadu sehingga dapat 
disimpulkan poin Administrasi dan Dokumentasi adalah poin yang paling prioritas untuk ditingkatkan kinerjanya karena sangat berpengaruh terhadap kinerja kompetensi manajemen kontraktor jalan untuk paket nonkecil di Provinsi Sumatera Barat.

\section{KESIMPULAN}

\subsection{Kesimpulan}

Berdasarkan hasil penelitian yang telah dilakukan dapat disimpulkan sebagai berikut :

1. Terdapat 9 faktor yang mempengaruhi kompetensi manajemen kontraktor jalan untuk paket non kecil yang bekerjasama dengan Dinas Prasarana Jalan, Tataruang dan Permukiman Provinsi Sumatera Barat yaitu Pengorganisasian sesuai dengan dokumen kontrak dan spesifikasi teknik, Rekayasa lapangan, Metode pelaksanaan dalam proses konstruksi, Keahlian dalam melakukan perhitungan biaya konstruksi jalan, Rencana dan pengendalian mutu, Waktu dan biaya, faktor Administrasi dan dokumentasi, Teknik negosiasi dan hubungan dengan masyarakat, Sumber daya.

2. Owner merasa puas terhadap kompetensi manajemen kontraktor paket nonkecil yang bekerjasama dengan Dinas Prasarana Jalan, Tataruang dan Permukiman Provinsi Sumatera Barat, hal ini dapat dilihat dengan nilai Customer Satisfaction Index (CSI) sebesar $69 \%$ yang terletak pada rentang nilai antara $65 \%<\mathrm{CSI} \leq$ $80 \%$ ) yaitu level ke IV (Puas).

3. Berdasarkan pemetaan kuadran dan gap analysis terdapat 3 faktor yang menjadi fokus dalam perbaikan yaitu faktor sistem manajemen pelaksanaan jalan, faktor administrasi dan dokumentasi dan faktor sumber daya.

4. Faktor administrasi dan dokumentasi adalah faktor yang memiliki Gap (selisih nilai) kebutuhan dan kepuasan yang paling besar sehingga menjadi faktor yang paling prioritas untuk ditingkatkan kinerjanya karena sangat berpengaruh terhadap kinerja kompetensi manajemen kontraktor jalan untuk paket nonkecil di Provinsi Sumatera Barat.

\subsection{Saran}

1. Objek pada penelitian ini adalah kontraktor jalan untuk paket nonkecil, untuk penelitian lebih lanjut dapat di ambil sampel kontraktor untuk paket kecil dan paket nonkecil sehingga dapat dibandingkan kinerja manajemen kontraktor jalan untuk paket kecil dan paket non kecil di Sumatera Barat.

2. Objek pada penelitian ini adalah kontraktor jalan, untuk penelitian lebih lanjut dapat di ambil sampel dari kontraktor bangunan dan air sehingga dapat dibandingkan kinerja manajemen kontraktor jalan dengan manajemen air dan bangunan.

3. Responden pada penelitian ini berasal dari owner, untuk penelitian lebih lanjut dapat ditambahkan responden dari konsultan pengawas agar dapat dibandingkan persepsi owner dengan persepsi konsultan pengawas selaku pihak yang terlibat langsung dengan managemen proyek jalan.

4. Untuk penelitian selanjutnya dapat ditambahkan analisa manajemen kontraktor berdasarkan pembagian zona wilayah kegiatan.

5. Variabel yang masuk dalam prioritas perbaikan dapat menjadi bahan pertimbangan untuk meningkatkan kinerja manajemen kontraktor nonkecil jalan di Provinsi Sumatera Barat. 


\section{DAFTAR PUSTAKA}

Chasanah. U. (2013) Thesis Komparasi Proyek Konstruksi Kontraktual Dengan Proyek Konstruksi Berbasis pemberdayaan Masyarakat. Tesis magister, Universitas Diponegoro.

Hermanto, A, W. (2008) Analisa Tingkat Kepuasan Konsumen Terhadap Pelayanan Terminal Peti Kemas Semarang. Thesis, Universitas Diponegoro.

Irianto, A. (2003) Statistik Konsep Dasar dan Aplikasinya. Jakarta : Prenada Media

Kementrian Pekerjaan Umum Direktorat Jenderal Bina Marga, 2014, Spesifikasi Umum Edisi 2010 (Revisi 3), Jakarta.

Khasani, R, R. (2013) Evaluasi Kepuasan Pelanggan Terhadap Kinerja Manajemen Proyek Kontraktor Besar Bangunan Gedung. Thesis, Universitas Diponegoro.

Lembaga Pengembangan Jasa Konstruksi, 2011, Peraturan Lembaga Pengembangan Jasa Konstruksi Nomor 02 Tahun 2011 tentang Tata Cara Registrasi Ulang, Perpanjangan Masa Berlaku dan Permohonan Baru Sertifikat Badan Usaha Jasa Pelaksana Konstruksi. Jakarta.

Lembaga Pengembangan Jasa Konstruksi (2013) Peraturan Lembaga Pengembangan Jasa Konstruksi Nomor 10 Tahun 2013 tentang Registrasi Usaha Jasa Pelaksana konstruksi, Jakarta.

Lukman. (2010) Survey Mengenai Pengaruh Penerapan ISO 9001 Terhadap Kualitas Proyek di PT. Pembangunan Perumahan Semarang. Thesis, Universitas Diponegoro.

Martilla, J. A. and John, C. J. (1977). Importance-Performance Analysis. The Journal of Marketing, 41(1), pp. 77-79.

Melriansyah,M (2011) Pemodelan Kompetensi Knowledge, Behavorial dan Contextual Manajer Proyek Sebagai Faktor Kesuksesan Manajer Proyek Terhadap Kinerja Biaya Proyek. Thesis.Universitas Indonesia.

Putra, C.G.D. (2011) Analisa Kepuasan Pelanggan Pada Perusahaan Daerah Air Minum (PDAM) di Kabupaten Jembrana. Thesis, Universitas Udayana Denpasar.

Setiawan, R. (2005) Analisa Tingkat Kepuasan Pengguna Kereta Api Komuter Surabaya-Sidoarjo. Surabaya. Thesis, Universitas Kristen Petra.

SKKNI, 2003. Manajer Pelaksanaan Pekerjaan Jalan (Site Manajer Of Road Construction), Departemen Pekerjaan Umum.

Soepono, B. (2002) Statistik Terapan Dalam Penelitian Ilmu-Ilmu Sosial dan Pendidikan. Jakarta : Rineka Cipta.

Supranto, J. (2002) Pengkuran Tingkat Kepuasan Pelanggan Untuk Menaikkan Pangsa Pasar. Jakarta : Rineka Cipta.

Susilo, B. (2000) Analisis Pengaruh Faktor Sikap, Keahlian dan Pengetahuan terhadap Kompetensi Manajemen Perusahaan Konstruksi dari Sudut Pandang Owner, Konsultan dan Sub Kontraktor (Studi kasus 4 perusahaan konstruksi golongan A di Surabaya). Thesis, Universitas Kristen Petra.

Yosritzal, dkk (2014) Studi Implementasi Metoda Importance-Satisfaction Analysis (ISA) pada Penentuan Prioritas Penanganan Pelayanan Kereta Api Padang-Pariaman. Ace Proceeding 1st, Universitas Andalas. 